\title{
Navigating and Circumventing (Self)censorship in the Chinese Music Scene
}

\section{Nathanel Amar}

Translator. Romain Dittgen

\section{(2) OpenEdition}

\section{Journals}

\section{Electronic version}

URL: https://journals.openedition.org/chinaperspectives/10107

DOI: 10.4000/chinaperspectives.10107

ISSN: 1996-4617

\section{Publisher}

Centre d'étude français sur la Chine contemporaine

\section{Printed version}

Date of publication: 1 June 2020

Number of pages: $25-33$

ISSN: 2070-3449

\section{Electronic reference}

Nathanel Amar, "Navigating and Circumventing (Self)censorship in the Chinese Music Scene", China

Perspectives [Online], 2020-2 | 2020, Online since 01 June 2021, connection on 06 July 2021. URL:

http://journals.openedition.org/chinaperspectives/10107; DOI: https://doi.org/10.4000/

chinaperspectives. 10107 


\title{
Navigating and Circumventing (Self)censorship in the Chinese Music Scene
}

\author{
NATHANEL AMAR
}

\begin{abstract}
Although the case of "censorship" of Chinese hip-hop in January 2018 has led to extensive news coverage in the international press, it does not account for the multiple forms of musical censorship that exist in contemporary China. This article draws on observations from within the punk rock community to outline how censorship works in practice and which institutions are responsible for overseeing musical productions, from the release of albums to the management of concerts and festivals. This overview of censorship mechanisms in the Chinese music scene - including self-censorship required to release albums domestically - will highlight how to circumvent censorship, as well as the extent to which it is possible for artists to negotiate with the authorities.
\end{abstract}

KEYWORDS: Censorship, self-censorship, music, China, popular culture.

$\mathrm{R}$ ecent cases of censorship and self-censorship conducted both by institutions of the People's Republic of China (PRC) and private actors have made international headlines. Surprisingly, it took a backlash at the NBA over a tweet supporting the Hong Kong 2019 antiextradition law protests, ${ }^{1}$ the ban of a Hong Kong Hearthstone gamer by Blizzard," and an episode of "South Park" ${ }^{2}$ to shed a light on the extent of censorship in the PRC and its impact abroad. Among all these controversies, which mostly concerned foreign companies sometimes getting ahead of the Chinese authorities' desires, music has been an important part of the recent crackdown. Songs related to the Hong Kong protests, such as "Do you hear the people sing?", 4 or to the democratic movement of 1989, have disappeared from the Chinese Internet. In contrast, music has also been used as a tool to resist PRC censorship in the Sinophone world, be it in Hong Kong during the protests, or in Taiwan with for instance the song "Tryna Bully" by the rapper Dwagie 大支. ${ }^{5}$ Musical censorship can take different shapes, from the online disappearance of songs and lyrics to visa bans and concert cancellations, but also self-censorship by private companies or individuals, in order to protect themselves or gain a bigger market share.

Most of the studies dealing with censorship in China are focused on the highly debated online censorship, with its armies of Internet users publishing nationalistic content nicknamed "fifty cents" (wumao 五毛, in reference to the salary the government is believed to grant them for each posted message, see Han 2015), its banned keywords ( $\mathrm{Ng} 2013$ ), the use of the meme - the replication of a cultural element shared on the Internet - as a challenge to censorship (Tang and Yang 2011), or the censorship system regarding literature and cinema (Veg 2007; Pernin 2015). Analyses of the institutional mechanisms presiding over the effective censorship of cultural works are, however, often absent - particularly in the case of music, with the exception of research conducted by Sabine Trebinjac (2000) on the "Regional administrative service of popular songs' compilations" (Diqu minjian yinyue jicheng bangongshi 地區民間音樂集成辦公室), which is tasked with the collection and categorisation of folk music, and Jeroen de Kloet's work on Chinese musical communities, and more precisely on "linguistic camouflage," when Chinese musicians have to falsify provocative lyrics (2010: 180-90). Following in the footsteps of this research, this article aims at identifying the official institutions responsible for musical censorship and how the Chinese musical world navigates these obstacles in order to produce and circulate music. What are the institutions involved in the censorship process? How can one negotiate with the authorities? Is there room for circumventing these written or unwritten rules? Drawing on observations and interviews conducted from 2011 onward in Beijing, Wuhan, Shenzhen, Changsha, and Tianjin within the Chinese punk rock music scene, which is regularly confronted with issues of censorship, this paper seeks to outline how musical censorship is practically implemented, as well as its most recent evolutions. These observations allow us to better understand how censorship and selfcensorship work today, and broaden the scope of past studies on rock (Jones 1992; Campbell 2011), underground music of the 1990s (Groenewegen 2011), and other genres not limited to the Chinese capital (Grillot 2001). Apart from the official institutions that artists have to contend with in order

1. Tripti Lahiri, "The backlash over China's NBA bullying is only going to get worse," Quartz, 18 October 2019, https://qz.com/1730643/china-asked-nba-to-fire-daryl-morey-for-hong-kongtweet/ (accessed on 2 November 2019).

2. Peter Allen Clark, "What to Know About Blizzard, Hong Kong and the Controversy Over Politics in Esports," Time, 21 October 2019, https://time.com/5702971/blizzard-esports-hearthstone-hongkong-protests-backlash-blitzchung/ (accessed on 2 November 2019).

3. Daniel Victor, "South Park Creators Offer Fake Apology After Show Is Erased in China," The New York Times, 8 October 2019, https://www.nytimes.com/2019/10/08/arts/television/south-parkchina.html (accessed on 2 November 2019).

4. "Do you hear the people sing? Not in China," The Economist, 14 June 2019, https://www. economist.com/prospero/2019/06/14/do-you-hear-the-people-sing-not-in-china (accessed on 2 November 2019).

5. See the videoclip of the song: https://youtu.be/zAfiz73FIsU (accessed on 2 November 2019). 
to release a record, they also have to deal with a range of actors - police officers, municipal agents from the Bureau of Culture, the cultural police, and municipal law enforcement officers - when they perform in public. First, I will outline how censorship of musical works has been organised since 1949, before delineating the mechanisms to which artists must conform when they release a record or organise a concert. Finally, I will show how recent cases reveal more discretionary practices of censorship, and raise concerns about the export of Chinese censorship to other regions of the Sinophone world.

\section{Institutions of cultural censorship}

The control of Chinese cultural expression was theorised very early by Communist Party leaders, most notably by Mao Zedong 毛澤東 in his 1942 "Talks at the Yan'an Forum on Literature and Art" (Mao 1942) - a theme already discussed at the Gutian 古田 conference in 1929 (Trebinjac 2000: 37). This cultural policy led to the promotion of artistic forms combining elements from popular Chinese culture with features from communist propaganda, such as the yangge 秩歌 dance, "a collective traditional dance, tied to the annual cycle of agricultural work, accompanied by songs and various musical instruments" (Graezer 1999: 31), used for propaganda purposes by the cultural cadres of the Chinese Communist Party (CCP), and appropriated during the Cold War by Sinophone leftist communities (Wilcox 2020). As of 1949, cultural production with regards to cinema, radio, and television was nationalised (Berry 2004). The Chinese Association of Musicians (Zhongguo yinyuejia xiehui 中國音樂家協會) was created in July 1949 to propagate music that conforms to Party requirements and to train a new generation of socialist musicians (Ju 2002), following on from the Association of Leftist Musicians (Zuoyi yinyue zuzhi 左翼音樂組織), created in 1932 and dissolved in 1936 (Trebinjac 2000: 24). Musical production was strictly controlled, as evidenced by the creation of the China Record Corporation (Zhongguo changpian jituan youxian gongsi 中國唱片集團有 限公司) in May 1949, which then held the monopoly of music distribution in the PRC. ${ }^{6}$ Chinese folk songs - including those by national minorities and from Hong Kong, Macao, and Taiwan - were collected and compiled by the "Administrative Service of Compilations," under the responsibility of the State Council and "comprised of at least ten thousand officials tasked with the collection of national music and, following censorship and selfcensorship, with the elaboration of a compilation" (ibid.: 129) in line with socialist values. The so-called "pornographic" songs (huangse yinyue 黄色 音樂, literally "yellow music"), in reality popular romantic songs produced in Shanghai in the 1930s, were banned, prompting Andrew F. Jones to argue that "Chinese music was shamelessly charged with the spreading of Maoist ideals of class struggle, revolutionary fervour and self-denial" (Jones 1992: 11-2).

Mao's death in 1976 and the launch of economic reforms by Deng Xiaoping 鄧小平 resulted in a relative relaxation of censorship regarding popular culture and an effervescence of the musical field. In spite of the sultry nature of her love songs, Taiwanese singer Teresa Teng (Deng Lijun 鄧 麗君) became extremely popular in the PRC with the emergence of pirated cassettes, to the point that a famous saying in the 1970s said that "old Deng [Xiaoping] rules by day, little Teng [Lijun] rules by night" (Gold 1993: 909). Artists who were independent from state-sponsored institutions began to organise, and new musical styles emerged, such as "prison songs" (qiuge 囚 歌), ${ }^{7}$ then Rock 'and' Roll (yaogun 搖滾) in the 1980s (Jones 1992). After a first wave of popularisation in the late 1980s, rock and roll and other cultural productions became firmly controlled after the Tiananmen crackdown, as major rock singers including Cui Jian 崔健 and He Yong 何勇 took position for the students in 1989, resulting in a "massive nationwide enforcement to sao huang 掃黃 (sweep the Yellow publications) annually since 1989" (Gao 2014: 129). In the mid-1990s, a new independent music scene emerged outside the official circuit, favoured by the appearance of pirated cassettes (daoban 盗版) by Taiwanese and Hong Kong artists such as Beyond, then of dakou tapes and CDs (打口, literally "broken") available on the black market in many Chinese cities. These CDs and cassette tapes, an embarrassing surplus of the Western music industry, were sent to China for recycling, but ended up being sold illegally at low prices in the streets of major Chinese cities from 1993 onwards (De Kloet 2005). Chinese youngsters, unable at the time to legally obtain Western music albums, mostly banned or sold at prohibitive prices, largely turned towards these trafficked products. New musical genres then appeared in major Chinese cities in the mid-1990s, ranging from alternative rock, punk, and hip-hop to metal. In that way, they bypassed official censorship as well as the music industry unable to satisfy them:

The rights to publish and reproduce print publications (yinshua chubanwu (印刷出版物) - tapes, videocassettes and optical discs) were exclusively entitled to a small number of state-owned presses, whose production capacities (in terms of both the variety of titles and the quality of the output) were quite incompatible with the citizens' enormous appetite for cultural products (...). (Gao 2014: 127)

The opening-up of the 1990s, and the blooming of new musical styles not approved by the authorities, did not significantly alter the censorship policies regarding musical content. The history of various administrative control bodies of cultural products also intersects with internal quarrels over the prerogatives granted to each administration. Music itself is governed by different institutions according to the way it is broadcasted. Censorship procedures and propaganda supervision were initially allocated to the Ministry of Radio, Film and Television (Guangbo dianying dianshi bu 廣播 電影電視部) until 1986, when it was replaced by the Film and Television Bureau, which in 1998 became the State Administration of Radio, Film and Television (SARFT, Guojia guangbo dianying dianshi zongju 國家廣播電影 電視總局), placed under direct supervision of the State Council (Latham 2005: 779) with "branch offices at all levels of government down to the township level" (ibid.: 778). Another body, the State Press and Publication Administration, established in 1954 and also monitored by the State Council, in charge of publications and copyrights, previously competed with the SARFT before being integrated into its fold in 1998 (Hu 2005: 781). In 2013, the SARFT became the State Administration of Press, Publication, Radio, Film and Television (SAPPRFT, Guojia xinwen chuban guang dian zongju 國 家新聞出版廣電總局), and was dissolved in March 2018 within the new National Radio and Television Administration (NRTA, Guojia guangbo dianshi zongju 國家廣播電視總局), under the direct supervision of the Propaganda Department of the Central Committee of the Chinese Communist Party (Zhonggong zhongyang xuanchuanbu 中共中央宣傳部), founded in 1924,

6. Since 2003, the China Record Corporation (CRC) has been controlled by the State Council (Guowuyuan 國務院), itself chaired by the Prime Minister. See the CRC website: http://www. china-crc.com.cn/View/2543.html (accessed on 30 June 2019).

7. A music fad associated with the "Northwest Wind" (Xibeifeng 西北風) musical genre, performed by ex-convicts or sent-down youth (zhiqing 知情) of the Cultural Revolution (see Baranovitch 2003: 26).

8. Pang-Chie Ho, "Goodbye, SAPPRFT (But not Chinese censorship)," SupChina, 21 March 2018, https://supchina.com/2018/03/21/goodbye-sapprft-but-not-chinese-censorship/ (accessed on 30 June 2019). 
and mainly in charge of information control. ${ }^{8}$ This recent decision, after years of centralisation, confirms the Party's drive to directly steer censorship bodies on behalf of the state and to directly take over the propaganda tools. Its main purpose is to regulate the media, issue publication authorisations, and supervise the distribution of cultural works. Henceforth also in charge of censorship on the Internet, it directly manages the main Chinese media groups, namely China Central Television (CCTV), China Radio International (CRI), and China National Radio (CNR). Since Xi Jinping's 習近平 presidency, the NRTA must also promote the "hegemonic discourse" carried out by the Party through officially broadcasted cultural works, by fostering "positive energy" (zhengnengliang 正能量) in culture and the media, as defined by Xi in 2013. This "positive energy" symbolises the "attitudes or emotions that are aligned with the ideological or value systems of the Party-state, or any discourses that promote such an alignment" (Yang and Tang 2018: 2). In a speech given in 2017, Xi Jinping insisted that "artists focus on the people during their cultural creation work, thereby providing strong spiritual power for the great rejuvenation of the Chinese nation (...) artists should work for the people and socialism." ${ }^{\prime \prime}$ On the other hand, the Ministry of Culture and Tourism (Wenhua he lüyou bu 文化和旅遊部) and the various local cultural bureaus are responsible for overseeing live music and live venues. ${ }^{10}$ Artists and managers therefore have to deal with different authorities when they release an album or a videoclip, or when they organise a concert.

\section{Negotiating with the authorities: Releasing an album, organising a concert}

Although the authorities in charge of regulating the cultural field are present at all administrative levels, many labels, media outlets, or producers of cultural content are not directly controlled by the state. State-owned enterprises and agencies delegate the task of publishing works that are adapted to the market to specific private companies through the attribution of official authorisations to publish (chubanwu 出版物, which include newspapers, books, audiovisual productions, and electronic publications) granted by the State Council, while being vigilant about the ideological content of these works, since publications should "promote the construction of the socialist spiritual civilization."11 In the 1980s and until the mid1990s, the first Chinese rockers Cui Jian, He Yong, Dou Wei 竇唯, and the heavy metal band Tang Dynasty (Tang chao 唐朝), bypassed the chubanwu by issuing a large portion of their cassettes through companies located in Taiwan or in Hong Kong, such as Rock Records (Yaoshi 搖石) or Magic Stone (Moyan changpian 魔岩唱片). But from the late 1990s onwards, the first independent labels were established, initially to circulate the works of the emerging rock scene. These labels were independent (duli 獨立), in the sense that they did not belong to state-controlled companies or to large record companies, but they nonetheless had to negotiate with state-owned music institutions in order to get these chubanwu. Shen Lihui 沈黎睴, the singer of the Brit-Pop group Sober (Qingxing 清醒), embodies a central figure in this new musical entrepreneurship. Previously a graphic designer for the China Record Corporation, Shen Lihui decided to self-produce rock albums, and in 1997 he founded the label Modern Sky (Modeng tiankong 摩登天空), allowing him to release that same year his band's first album, which sold at 150,000 official and 300,000 illegal copies (Steen 2000: 7). Modern Sky also set up a label devoted to alternative music, Badhead Records, and produced most of the records by groups in the "New Beijing sound" movement (Beijing xinsheng 北京新聲; see Ou, Yan, and Nie 1999). Some have accused Modern Sky of commercialising, and thus over-formatting Chinese rock music, while others have pointed to the "typical post-modern PRC paradox" (Steen 2000: 9) that Modern Sky would represent for the Chinese music industry, always overly cautious when it comes to releasing rock albums. In 1999, Scream Records (Haojiao changpian 嚎叫唱片) was created out of the ashes of the punk bar Scream Club (Haojiao julebu 嚎叫俱樂部), and produced the first albums of the capital's punk, metal and hip-hop communities. Artist Lü Bo 呂波 and rocker Wang Di 王迪 produced the first album of Wuliao Jundui (無聊軍隊, literally "the Boredom Contingent"), the first Beijing punk collective, in collaboration with Jing Wen Records (京文), a label specialising in the import of foreign albums. Other labels were put in place throughout the 2000s, including Maybe Mars (Bingmasi 兵馬司), created in 2007 by the American Michael Pettis, which produced a number of independent bands that emerged in the mid-2000s thanks to the D-22 bar in Beijing, also owned by Pettis. The D-22 closed its door in 2012, and its successor, the XP, was forced to do the same in July 2015, after inviting the Japanese artist Makoto Kawabata, who was blacklisted by the Beijing municipal government. ${ }^{12}$ As for Maybe Mars, it was sold in 2018 to the large company Taihe 太合, now taking advantage of this to commercialise its catalogue by making its rock artists participate in TV talent shows, ${ }^{13}$ which require bands to change their lyrics. ${ }^{14}$

Although these labels are not directly controlled by the state, they still need support from official labels to legally publish music content. A common practice consists of purchasing ISRC (International Standard Recording Code) numbers, as a Maybe Mars employee recalls:

We cannot release our own albums ourselves. We need to buy ISRC numbers from official labels. Since they have too many of them and need the money, they can sell some of them to independent labels, and, as a result, do not lose their quota of ISRC numbers granted by the government. Before being able to release an album, we must submit the lyrics of the songs, so that they validate them. That is why sometimes we have to change the lyrics ourselves before submitting them. If we release a CD that does not appeal to the government, the administration will turn against the label that sold us the ISRC numbers; they will receive fewer numbers, and will stop selling to us. ${ }^{15}$

The same process is also at work when it comes to books; as Sebastian Veg points out, "Books must similarly obtain an ISBN number, which certain state publishers sell to smaller and more independent publishers willing to take the risk of a subsequent ban after publication" (2007: 66-7). In other

9. An Baijie, "Xi urges artists to focus on the people," China Daily, 28 September 2017, http://www. chinadaily.com.cn/china/2017-09/28/content_32580095.htm (accessed on 20 June 2019).

10. Jiayun Feng, "Inside China's ever-evolving censorship apparatus," SupChina, 23 August 2019, https://signal.supchina.com/inside-chinas-ever-evolving-censorship-apparatus/ (accessed on 2 November 2019).

11. Article 1 of the "Regulations on publishing management" (Chuban guanli tiaoli 出版管理條例) of the State Council: http://www.gov.cn/banshi/2005-08/21/content_25110.htm (accessed on 30 June 2019).

12. See Yan Jun, "Drugs, Violence, Porno, Mafia, Anti-government, Anti-religion and Acid Mothers Temple," Wire, May 2015, https://www.thewire.co.uk/in-writing/columns/yan-jun_drugs_ violence_porno_mafia_anti-government_anti-religion-and-acid-mothers-temple (accessed on 30 June 2019).

13. See Fan Shuhong, "Is 'The Big Bang' About To Do for Rock Music What 'Rap of China' Did for Hip Hop?," RadiiChina, 19 May 2019, https://radiichina.com/the-big-band-iqiyi-rock-reality-tv/ (accessed on 30 June 2019).

14. For instance, the band Hedgehog (Ciwei 刺猬) had to change the lyrics "Society is a pain competition" (shehui shi shanghai de bisai 社會是傷害的比賽) into "Time is a pain competition" (shijian shi shanghai de bisai 世間是傷害的比賽) during The Big Band TV show. See 樂隊的夏天歌詞刪改匯總 (Yuedui de xiatian geci shangai huizong, A summary of lyrics deletion in The Big Band), Yousuodu, 4 August 2019, https://mp.weixin.qq.com/s/ K1tj6ynlx9QWDTu2mwKd2A (accessed on 14 September 2019).

15. Interview, Beijing, 14 December 2014. 
words, in the case of music albums and books, state publishers outsource the risk of censorship to independent companies. In this case, censorship plays out at different levels. If a band wants to officially release an album - that is to say, sell it via the authorised commercial circuits or on the Internet - it must submit its songs to the label's administration, where a first selection takes place. Bands and labels very often modify the lyrics of the songs in order to adapt to the norms defined by the SAPPRFT, and most often anticipate the decisions of the Censorship Bureau. As Jeroen de Kloet points out, "besides establishing and maintaining good relations with the authorities, a good publisher knows the right tactics to employ when negotiating the rules" (2010: 183). Thus, to avoid being accused of promoting pornography, bands and publishers change offending terms, even in English, for instance changing "fuck" to "funk" in the case of the Wuliao Jundui, or turning "sex" (xing 性) into "heart" (xin 心) for The Fly (Cangying 荅蠅) (De Kloet 2010: 185). Similar practices of self-censorship occur in other contexts, namely religious ones, when it comes to compiling Uyghur folk songs, as noted by Sabine Trebinjac: "Lyrics are changed in order to make too religious or amorous references more discreet" (2000: 363).

It is not only the lyrics, but also the sounds that must fit the requirements of the state institutions. But sound can also be used to hide problematic words. In the music video of the song "Awakening" (Juexing 覺醒), by one of the first Beijing punk bands UnderBaby (Dixia ying'er 地下嬰兒), the lyric "I want to take my blood and shit, and throw it onto the flag"16 posed a particular challenge for the label. The producers of the clip therefore decided to add the diegetic sound of a truck in order to skilfully cover the subversive sentence.

Selling albums the official way implies a negotiation with the authorities, and some bands navigate between official and underground publications depending on the political content of their albums. For instance the Wuhan punk band SMZB (Shengming zhi bing 生命之餅) published an album with the label Scream Records and distributed by the China Records Corporation in 2001, but their label decided not to even apply for an ISRC number in 2014 for the album A Letter From China (Zhongguo laixin 中國來信), which featured pictures of the Tiananmen protests.

The mere act of setting up a live performance requires the agreement of local bureaus of the Ministry of Culture, delivered through administrative procedures that few live venues can afford to apply for. Already in the 1980s, the nascent Chinese rock community had to find alternative spaces to perform. Although they started playing in several universities in the capital, it was in international hotels and restaurants, less subject to control by the authorities, that the Beijing "rock circle" (yaogun quan 搖滾圈) really thrived (Capdeville-Zeng 2002). From the late 1980s onwards, under the impulse of Li ji 李季 of the band Bu Dao Weng 不倒翁, rock live performances took the form of a "party" (the term used in rock circles), improvised performances in bars of the capital, without any authorisation from the municipality. In 1992, Li Ji opened up a space devoted to these "parties," the Happy Club (Xinfu julebu 幸福俱樂部); it closed down quickly after facing pressure from the Beijing municipal authorities (Xue 1993: 282). In 1995, Liu Yuan 劉元, Cui Jian's trumpet player, opened the CD Café, which hosted the capital's rock and underground scene, and allowed Cui jian to perform in public, although he was officially banned from performing in Beijing from 1989 to 2007. ${ }^{17}$ In Cui Jian's case, censorship paradoxes are amplified. He was allowed to organise a (shortened) tour in 1990 to promote the Asian Games, a few months after the 1989 repression (Campbell 2011: 85), but he also had to confront provincial administrations - for instance, in 1995 an authorised performance in Taiyuan 太原 was abruptly cancelled by the provincial government without explanation. ${ }^{18}$ These are problems that other music communities also dealt with in the mid-1990s: without the necessary authorisations - the licence to perform in public (yanchuzheng 演出證) is issued by the central government - concerts can be interrupted by the police, as the American David O'Dell writes in his memoirs (2011:29).

Since this permit is difficult to obtain, most live venues do without it. A concert organiser in Beijing describes how best to avoid interference by the authorities:

You have an official, semi-official, and underground way to organise concerts. [F]or an official concert (...), there are some state-owned companies or national stages that have the licences and authorisation to submit the application, by presenting the artist's lyrics, which requires lots of time and money. Generally, we mainly opt for the second way; we go through something semi-official; we would introduce the artist to the Bureau of Culture, inform the police of the artist's arrival and we can sell tickets although not in the official network. The third option is to hold concerts in prohibited places, like parties, or in cellars; and there you can end up having real problems. ${ }^{19}$

Censorship and self-censorship are not only administrative; they are often embodied by the figure of the police officer, seen as a last resort to prevent concerts from happening.

\section{"They switched off the sound...": Confrontations with the police}

On 9 August 2014, a scene familiar to the Chinese underground music scene took place in Beijing's Chaoyang district. Ten police officers arrived at 2 Kolegas (Liangge haopengyou 兩個好朋友), a bar that hosted not only a yearly punk festival, but also various other musical genres, including techno music. After a compulsory urine test for all the audience, nine individuals were arrested on drug-use charges, including five foreigners who were immediately escorted back to the border. The bar was forced to close. ${ }^{20}$ Police interventions vary according to various political meetings and governmental campaigns against pornography, foreign influence, or drug consumption.

Police raids are most often a source of conflict and financial problems for live venues, but also provide opportunities to negotiate with the police on a case-by-case basis, through bribes and persuasion. In Wuhan, in 2011, the police tried to cancel a SMZB concert:

We were booked to perform at the VOX Livehouse; 700 people had bought their tickets in advance. People started lining up in the afternoon; at $5 \mathrm{pm}$ the cops arrived. They said that there were too many people, and that the concert needed to be cancelled. I arrived and talked to them. I told them that people had already bought their

16. “我要把我的熱血和大便都通通拋在這旗幟上面” (Wo yao ba wo de rexue he dabian dou tongtong pao zai zhe qizhi shangmian).

17. Cui Jian was not allowed to perform officially in Beijing until 2007, even if this ban was not strictly enforced. For instance, this is a video of a concert organised by the French Embassy in 1997: https://youtu.be/r8Rs1NUaUNg (accessed on 30 June 2019).

18. See the interview of Cui Jian by BBC World in 1995: https://youtu.be/53E2lj9uvP0?t=211 (accessed on 30 June 2019).

19. Interview, Beijing, 26 May 2012

20. Jared Cline, "2 Kolegas random drug test sees nine arrested," TimeOut Beijing, 11 August 2014, http://www.timeoutbeijing.com/features/Blogs-Nightlife_Blogs/31906/2-Kolegas-random-drugtest-sees-nine-arrested.html (accessed on 30 June 2019). 
tickets, and that they could not do this. After talking for half an hour, they agreed to only let in 200 people. Then, throughout the entire concert, there were cops standing inside and outside the venue... ${ }^{21}$

In general, police intervention during a concert is due to the size of the audience. This especially affects major rock festivals and pop concerts that can host tens of thousands of spectators. The use of physical violence by police during concerts sporadically sparks indignation online. In 2018, a video shot during a concert by the English pop singer Dua Lipa in Shanghai, showing security agents hitting spectators who were waving a LGBT flag, or who had stood up from their seats to dance, caused a scandal both abroad and in China. ${ }^{22}$ This is in fact typical of crowd control during concerts: in 1986, during a Shanghai performance of the American surf-rock band Jan and Dean, police officers "completely foreign to this kind of behaviour" hit spectators who had risen to dance, triggering a student demonstration in Shanghai (Baranovitch 2003: 35). Large music festivals are also the stage for new forms of security experiments, as with the Midi Music Festival (Midi yinyuejie 迷笛音樂 節) in Shenzhen, held on 30-31 December 2017, with X-ray security gates, identity card scans, and facial recognition, supervised by policemen (jingcha 警察), special security guards (tebao 特保) from the Longgang 龍崗 district, and private security guards (bao'an 保安). The Shenzhen police intended to criminalise all expressions of joy usually associated with rock concerts, such as pogos and stage-diving, where a spectator jumps into the crowd and is carried at arm's length. At each attempt of stage-diving, three police officers forced their way through the crowd to brutally pull the transgressor to the ground, before arresting and escorting the latter out of the festival. These stage-dives also provided an opportunity for festival-goers to showcase a great deal of

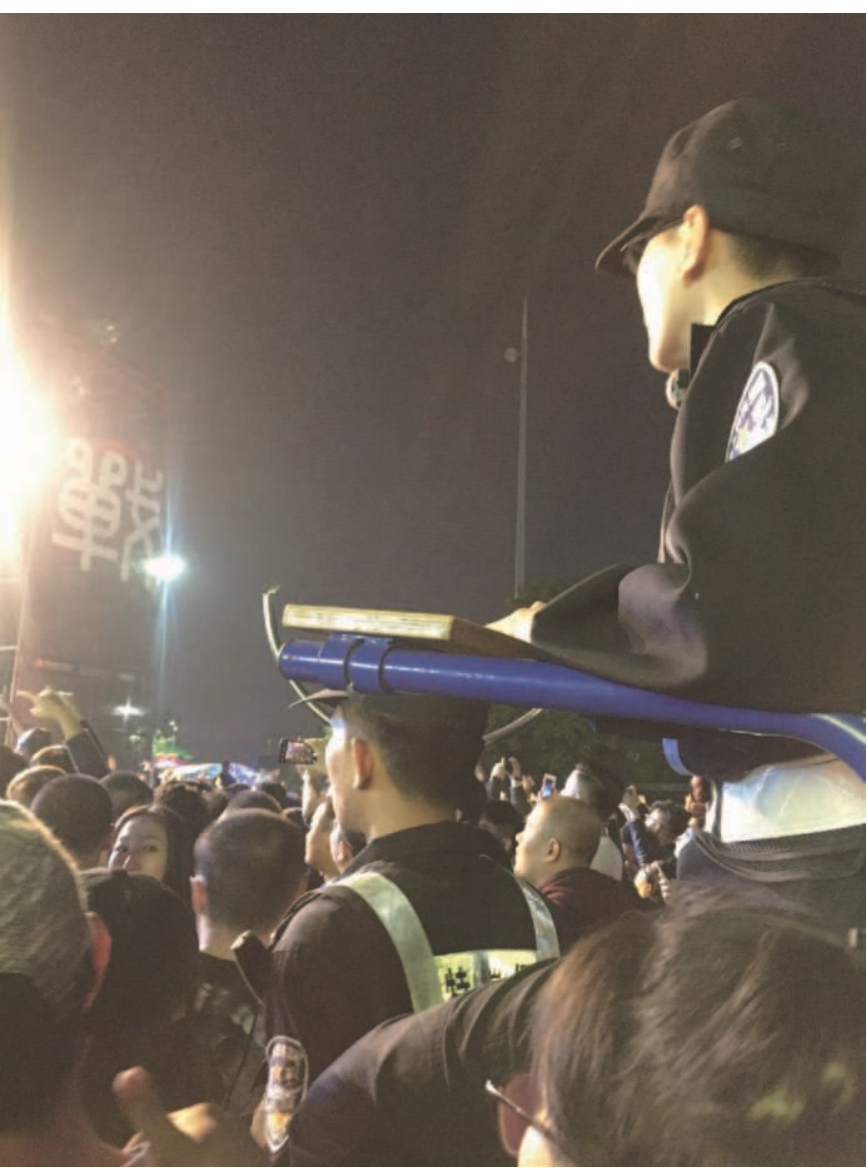

Figure 1. Police presence during concerts, Shenzhen Midi Music Festival, 31 December 2017. Photo credit: author. solidarity. Pretexting a stampede, the audience physically placed themselves between the police and the stage-diver, thus giving him or her time to escape. Police interventions culminated during the last performance of the festival; while SMZB played on the main stage, policemen arrested countless stage-divers. Despite submitting their song list in advance for approval by local authorities, SMZB members decided to perform an unapproved song, "Smash His Statue" - a reference to Mao's statues - while screening a video of Tiananmen Square behind them. After a few seconds, the projector was switched off along with the singer's microphone, while the tens of thousands of spectators resumed the rest of the song in chorus. This performance earned the band several hours at the police station before they were released with a simple slap on the wrist.

The practice of denouncing has also grown in popularity in recent years with the possibility of filing complaints on the websites of various administrations. ${ }^{23}$ In December 2017, a certain Liu Haizhu 劉海柱 filed a complaint on the website of the Beijing Municipal Bureau of Culture (Beijing shi wenhuaju 北京市文化局), demanding the ban of SMZB's live performance at the new MAO Livehouse in Beijing, and accusing the band of "discrediting the Communist Party, of diminishing the prestige of social stability and nation-building," by quoting the lyrics of one song praising the guitarist's grandfather, a nationalist soldier killed during the War of Resistance against Japan ${ }^{24}$ (Figure 2). According to band members, the complaint was most likely related to a grim story of enmity with the owners of this new live venue located in Beijing's Wukesong district. The concert was not cancelled, but a diffuse tension was palpable throughout the performance: the manager of the venue got on stage several times to ask the singer to stop talking directly to the audience, and agents of the Municipal Bureau of Culture were present at the venue. A similar complaint was filed on the same website, this time against the metal band Voodoo Kongfu (Lingyi 零壹) at one of the band's concerts at Yugong Yishan 愚公移山 in Beijing. The band was accused of "drinking blood on stage, using violence and pornography, and singing vulgar and reactionary songs."

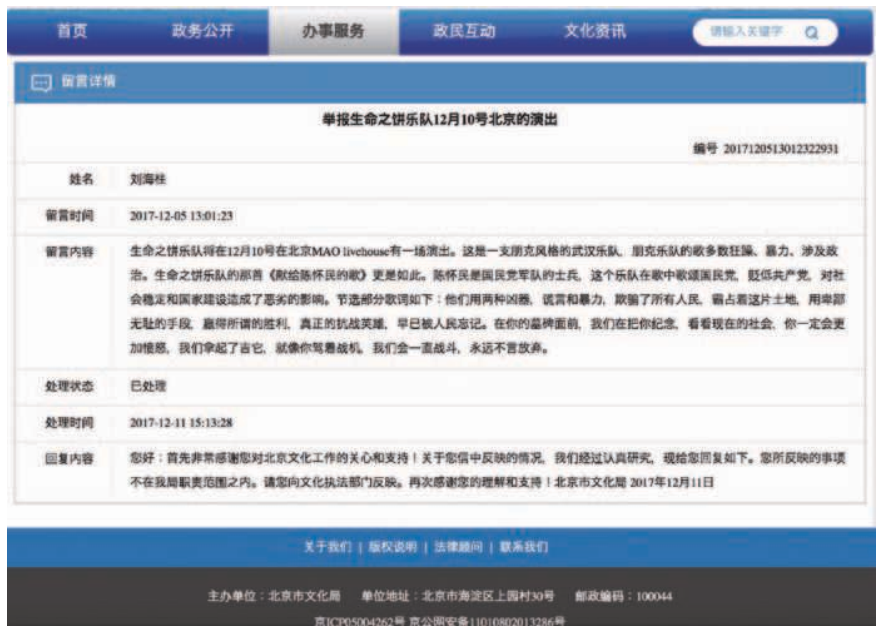

Figure 2. Screenshot of the complaint submitted to the website of the Beijing Municipal Bureau of Culture, 5 December 2017. Image provided by the author.

21. Interview, Wuhan, 18 December 2012.

22. Laura Snapes, "Dua Lipa 'proud' of fans ejected from concert for waving LGBT flags," The Guardian, 13 September 2018, https://www.theguardian.com/music/2018/sep/13/fansremoved-dua-lipa-shanghai-concert-china (accessed on 30 June 2019).

23. For a more comprehensive history of the complaints addressed to the Chinese administration, see Thireau and Hua (2010).

24. See the music video: https://www.youtube.com/watch?v=ZJ3WZi_gwwM (accessed on 30 June 2019). 
While these complaints did not result in cancelling the concerts, others succeeded in provoking cancellations and the closing down of venues. For instance, a live venue in Wuhan had to cancel a performance after a police raid: "Apparently, someone denounced us, saying that we didn't have the authorisation for hosting a foreign band. The police imposed a 20,000 yuan fine on the bar." ${ }^{125}$ More recently, the control of foreign artists has taken the form of economic pressure, especially since February 2019, when the National Tax Administration (Guojia shuiwu zongju 國家税務總局) announced that all concerts by foreign bands (including artists coming from Hong Kong, Macao, and Taiwan) would be taxed at $20 \%$ of all generated revenue. Some, like the journalist Wu Ying 武攖 in an article for the magazine $Q$ Music, ${ }^{26}$ predicted the end of concerts by foreign bands in China, and a "return to the dakou era," during which foreign music was only available on the black market.

\section{From the "hip-hop ban" to the disappearance of $L i$ Zhi:Acceleration of censorship during the Xi era}

The case of Chinese hip-hop is paradigmatic of the evolution of Chinese censorship, given that its status has evolved over time, moving from being blacklisted to being co-opted by the Party due to its popularity. Initially confined to the musical underground of the 1990s with the creation of the so-called "Iron Mic" (Gangtie maike 鋼鐵麥克) rap contests, Chinese hip-hop has gained wide popularity in recent years. In 2015, People's Daily (Renmin ribao 人民日報) announced the blacklisting by the Ministry of Culture of 120 songs promoting "obscenity, violence, crime, and immorality, ${ }^{127}$ which were removed from online streaming platforms. On this list, the majority were hip-hop bands from China, Taiwan, and Hong Kong, such as MC HotDog, a popular Taiwanese rapper. The Ministry of Culture's list backfired, making previously unknown hip-hop bands such as In3 (Yinsan'er 陰三兒) famous overnight, ${ }^{28}$ and had surprisingly little impact, since MC HotDog participated a few years later as a jury member for the popular talent show The Rap of China (Zhongguo you xiha 中國有嘻哈), broadcasted online by iQiyi from June 2017, alongside Taiwanese singers Will Pan 潘瑋柏 and Chang Chen-yue 張震嶽 and Chinese-Canadian pop-star Kris Wu 吳亦凡.

Overwhelmed by the growing popularity of the reality TV show and of hip-hop in general - with more than 2.68 billion online views for the first season of The Rap of China ${ }^{29}$ - on 19 January 2018, the SAPPRFT is believed to have banned from television "representatives of the hip-hop culture and its sub-culture" as well as tattooed individuals. ${ }^{30}$ This decision followed a scandal provoked by the Communist Youth League (Gong ging tuan 共青 團), which on its Weibo 微博 account accused PG-One, one of the winners of The Rap of China, of promoting drug use and sexism in one of his older songs (Amar 2018). Straight after, all the national media outlets cancelled on-air appearances by Chinese rappers, while streaming websites removed rap songs from their platforms. This decision, however, sparked many debates in the Chinese press, especially since it was not officially announced - the SAPPRFT notice and a screenshot of it, published by the Sina portal, remain unconfirmed. Media outlets and online streaming platforms nevertheless took the precautionary measure of removing any rap-like songs, exceeding the expectations of censorship institutions to the point of banning hanmai 喊 麥, a popular music genre on video-sharing platforms and akin to hip-hop. ${ }^{31}$ This so-called censorship of an entire music genre, which received a lot of media attention, did not last, however, as The Rap of China returned for a second season in 2018, then a third one in 2019. If PG-One has become more discreet, his co-winner CAl, also a victim of the "hip-hop ban," has returned to centre stage with songs more directly in line with the slogans of the authorities, such as "Great Wall" (Wanli changcheng 萬里長城), produced by the clothing brand Lining 李寧. ${ }^{32}$ In the same manner, the Party tends to co-opt hip-hop artists in order to spread specific messages among the youth, using a cannier technique than censorship. For instance, videos by Chongqing nationalist rap band CD-Rev (Tianfu shibian 天賦事變), which mostly target the United States and Taiwanese President Tsai Ing-wen 蔡英文, are funded by the Communist Youth League. In March 2019, during the National People's Congress and the Chinese People's Political Consultative Conference (Lianghui 兩會), the official Xinhua News Agency 新華社 posted a song performed in English by Su Han 宿涵, a rapper and student of biomedical engineering at Tsinghua University, entitled "Two Sessions," supposedly boasting about the merits of these plenary meetings, but it became the laughing stock of the international press and Chinese Internet users. ${ }^{33}$

Although the January 2018 "hip-hop ban" showcased the contradictory mechanisms of state censorship, other recent practices, more discreet, reveal an attempt at heightened control of Chinese music production. In November 2018, the online magazine Gang of Rock (Yaogun bang 搖滾幫) shared on Weibo a video of Cui Jian's song "A Piece of Red Cloth" (Yi kuai hongbu 塊紅布, 1991), which can be interpreted, like many of his songs, as a thinly veiled critique of the communist regime and of the repression of the 1989 movement. A few hours later, the Weibo message and Cui Jian's song had disappeared. Moreover, since the end of 2018, almost all of Cui jian's songs have simply been removed from online streaming platforms (Xiami, QQ Music, Baidu Music amongst others), including "Yi wu suo you" (一無所有), certainly the most popular Chinese rock song. Cui jian is not the only victim of this sudden and unexplained level of censorship: Zhou Yunpeng 周雲蓬, a visually-impaired folk singer from Shenyang, as well as Miserable Faith (Tongku de xinyang 痛苦的信仰), a nü-metal band reconverted into reggae, have seen some of their titles disappear from Chinese online streaming platforms.

25. Interview with Wu Yong (pseudonym), Wuhan, 1 September 2018.

26. The article was quickly removed from the website by the magazine, but can be found in the China Digital Times archives: https://chinadigitaltimes.net/chinese/2019/01/qthemusic-\%e6\%8 8\%91\%e4\%bb\%ac\%e6\%98\%af\%e4\%b8\%8d\%e6\%98\%af\%e5\%86\%8d\%e4\%b9\%9f\%e7\%9 c\%8b\%e4\%b8\%8d\%e5\%88\%b0\%e5\%a4\%96\%e5\%9b\%bd\%e4\%b9\%90\%e9\%98\%9f\%e 7\% 9a\%84\%e6\%bc\%94\%e5\%87\%ba\%e4\%ba\%86\%ef\%bc\%9f/?\%2F (accessed on 30 June 2019).

27. Huang Wei 黃維, “文化部首次公佈120首網絡音樂產品黑名單將依法查處” (Wenhuabu shouci gongbu 120 shou wangluo yinyue chanpin heimingdan jiang yifa chachu, The Ministry of Culture published an online blacklist of 120 songs ultimately to be examined according to the law), 人民日報 Renmin ribao, 10 August 2015, http://culture.people.com.cn/n/2015/0810/ c87423-27439050.html (accessed on 30 June 2019).

28. Tiffany Ap, "China's Online Ban Against 'Fart' and 119 other 'Immoral' Songs," CNN, 12 August 2015, https://edition.cnn.com/2015/08/12/asia/china-song-ban/index.html (accessed on 30 June 2019). The band $\ln 3$ was nonetheless arrested and detained for five days following a concert in Kunming; see Jamie Fullerton, "China's Hip-hop Stars Feel the Heat of Xi Jinping's Battle to Control Culture," The Guardian, 5 February 2016, https://www.theguardian.com/world/2016/ feb/05/chinas-hip-hop-stars-feel-the-heat-of-xi-jinpings-battle-to-control-culture (accessed on 30 June 2019).

29. Meng Jing, "'China's Netflix' scores massive hip-hop talent show blockbuster thanks to Al," South China Morning Post, 31 January 2018, https://www.scmp.com/tech/china-tech/article/2131206/ chinas-netflix-lands-itself-massive-reality-tv-blockbuster-use (accessed on 30 June 2019).

30. “總局提出節目嘉賓標準: 格調低紋身嘻哈文化不用” (Zongju tichu jiemu jiabin biaozhun: ge tiaodi wenshen xiha wenhua buyong, The Central Bureau promulgates standards for guests on programs: We do not want vulgarity linked to hip-hop and to tattoos), 新浪娛樂 (Sinlang Yule, Sina), 19 January 2018, http://ent.sina.com.cn/tv/zy/2018-01-19/doc-ifyquptv7935320.shtml (accessed on 30 June 2019).

31. Kenrick Davis, "China's Hip-Hop Haters Turn Their Ire to 'Hanmai',"Sixth Tone, 30 January 2018, http://www.sixthtone.com/news/1001631/chinas-hip-hop-haters-turn-their-ire-to-hanmai (accessed on 30 June 2019). See also Zhang and Xu 2019.

32. See the music video, in which GAI skillfully hides his many tattoos: https://youtu.be/ciZvgDvec38 (accessed on 30 June 2019).

33. Adan Kohnhorst, "China's Newest Propaganda Rap Video is Goddamn Ridiculous," RadiiChina, 4 March 2019, https://radiichina.com/chinas-newest-propaganda-rap-video-is-goddamnridiculous/ (accessed on 30 June 2019). 
This recent musical censorship has had very tangible consequences for some artists. In 2019, folk singer Li Zhi 李志, who had stood out the previous year for suing a reality TV show, ${ }^{34}$ was forced to cancel his Sichuan tour the day before his first concert. In a Weibo message posted in February 2019, Li Zhi professed health issues, with a photo attached, and announced that he would refund the 18,000 tickets already purchased. A few days later, Chinese and international media revealed without further details that the singer had to cancel his tour due to "inappropriate behaviour." ${ }^{135}$ In April, all of Li Zhi's social network accounts (Weibo, Douban...) disappeared, along with all of his songs. There has been no more news of Li Zhi, and no one knows of his whereabouts for the time being. ${ }^{36}$ The Chinese music community mobilised to pay homage to the folk singer, such as during the 2019 Midi festival, where he received the singer of the year award in absentia. The cautious announcement of the results on Weibo - the Midi festival having announced the awarding of the price to a "citizen of Nanjing, Mr. Li" (Nanjing shimin Li xiansheng 南京市 民李先生) - was censored a few hours after its publication (Figure 3).

In all likelihood, the disappearance of Li Zhi and the removal of Chinese rock songs of the 1980s from the Chinese internet are attributable to a tightened

\section{〈首页 微博正文 $\cdots$ \\ 0 迷笛

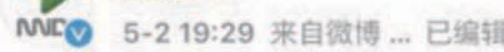 \\ 第十届\#中国摇滚迷笛奖\#颁奖典礼唐舞台进 行中, 恭喜以下获奖音乐人!}

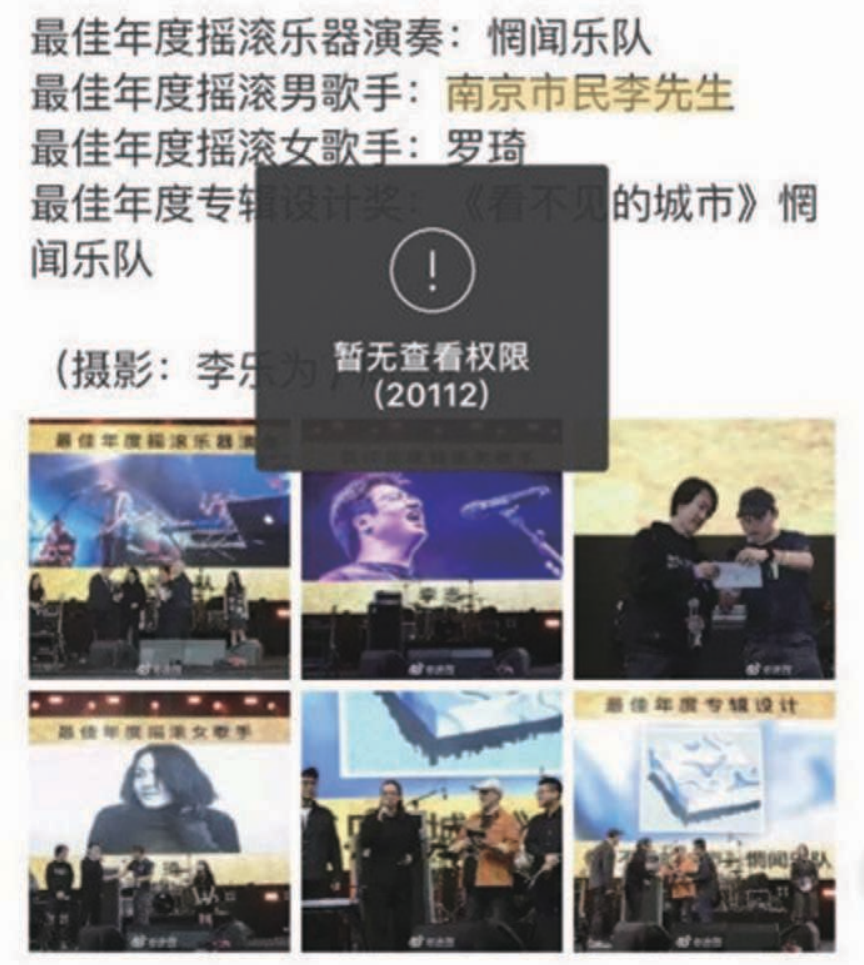

转发

四评论

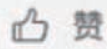

Figure 3: Screenshot of the censored message posted by the Midi Weibo account, announcing the winners of the 2019 Midi awards (reference to Li Zhi highlighted by author). Screenshot provided by the author. political atmosphere on the eve of the Tiananmen democratic movement's thirtieth anniversary, Li Zhi and Cui Jian's songs being directly or indirectly linked to the 1989 student movement. This censorship of musical work is not confined to titles produced by artists from China, or solely to online music streaming platforms owned by Chinese companies. Apple Music was forced to remove the songs of pro-democracy Hong Kong artists such as Tat Ming Pair 達明一派 and Denise Ho Wen-see 何韻詩 ${ }^{37}$ from its Chinese store, as well as a song by Cantopop singer Jacky Cheung 張學友, "The Way of Man" (Jan gaan dou 人間道, 1990), composed by James Wong for the movie $A$ Chinese Ghost Story II, since it also refers to the Tiananmen massacre. Following the 2014 Umbrella movement and the protests against the 2019 extradition bill in Hong Kong, a large number of songs related to the protests were censored or removed from the Chinese internet. As a result, the song "Do you hear the people sing," from the musical Les Misérables and sung by Hong Kong protestors, and Cantopop song "Queen's Road East" (Wong hau daai dou dung 皇后大道東, 1991) by singers Lo Ta-yu 羅大佑 and Ram Chiang 蔣志 光 from Taiwan and Hong Kong respectively, and referring to the reversion of sovereignty, both disappeared from Chinese platforms. ${ }^{38}$

Chinese censorship thus extends beyond the borders of the PRC, targeting Chinese-speaking artists from Taiwan and Hong Kong. Economic pressure also tends to export practices of self-censorship, with artists becoming "blacklisted" as soon as they display positions that are contrary to the injunctions of the Chinese regime. These practices are not new and fluctuate according to historical circumstances. Already after 1989, the Taiwanese singer Hou Dejian 侯德健 was banned from China for having supported the students, before being able to move back to Beijing in 2006 and composing a song in 2018 that glorifies Xi Jinping's "Chinese dream" (Zhongguo meng 中國夢). ${ }^{39}$ Similarly, Taiwanese Mandopop singer A Mei 張惠妹 could not perform in the PRC for several years after singing the Taiwanese national anthem during Chen Shui-bian's 陳水扁 inauguration ceremony in 2000, forcing Coca-Cola to replace A Mei in its commercials in the PRC. ${ }^{40}$ Denise Ho, who sided with the Democratic camp in Hong Kong, can no longer perform in the PRC and estimates in an interview that she "lost several million Hong Kong dollars after her music was removed from sale in China and she was blacklisted." ${ }^{\prime 41}$ The pro-independence Taiwanese metal band Chthonic (Shanling 閃靈), led by singer and MP Freddy Lim 林迌佐, had to cancel its participation in a

34. Nicole Lim, "Singer Sues Idol Show for Illegally Using His Music," Sixth Tone, 17 July 2018, https://www.sixthtone.com/news/1002623/singer-sues-idol-show-for-illegally-using-his-music (accessed on 30 June 2019).

35. David Bandurski, "Was Singer Li Zhi Censored in Sichuan?", China Media Project, 8 April 2019, http://chinamediaproject.org/2019/04/08/was-singer-li-zhi-censored-in-sichuan-2/ (accessed on 30 June 2019).

36. Fan Shuhong, "Where is Li Zhi? Outspoken Folk Musician Seemingly Scrubbed from Internet," RadiiChina, 14 April 2019, https://radiichina.com/li-zhi-outspoken-folk-musician-copyrightdefender/ (accessed on 30 June 2019).

37. Holmes Chan, "Apple Music in China removes Jacky Cheung song with reference to Tiananmen massacre," Hong Kong Free Press, 9 April 2019, https://www.hongkongfp.com/2019/04/09/ apple-music-china-removes-jacky-cheung-song-reference-tiananmen-massacre/ (accessed on 30 June 2019).

38. Echo Huang, "People in China are using song lyrics as code to voice support for Hong Kong," Quartz, 14 June 2019, https://qz.com/1643804/chinese-internet-users-turn-to-songs-to-discusshong-kong-protests/ (accessed on 30 June 2019).

39. Tianyu M. Fang, "How Hou Dejian went from Tiananmen protester to composer of the patriotic song 'Chinese Dream'," SupChina, 15 February 2019, https://supchina.com/2019/02/15/fridaysong-how-hou-dejian-went-from-tiananmen-protester-to-composer-of-the-patriotic-songchinese-dream/ (accessed on 30 June 2019).

40. "China bans Taiwan's Madonna," BBC News, 24 May 2000, http://news.bbc.co.uk/2/hi/asiapacific/761908.stm (accessed on 30 June 2019).

41. Erin Hale, "The Hong Kong celebrities risking careers to join protests," Al Jazeera, 25 June 2019, https://www.aljazeera.com/indepth/features/hong-kong-celebrities-risking-careers-joinprotests-190624110839766.html (accessed on 30 June 2019). 
concert in Hong Kong in December 2018, organised by Denise Ho. Hong Kong Immigration refused to grant working visas to the members of the band given that they "lack special skills, knowledge or experience." ${ }^{\text {"2 }}$ Thus, mainly in Hong Kong, mechanisms of censorship and self-censorship are being implemented, gradually shifting from economic pressure to more direct forms of intervention in cultural affairs by the authorities.

\section{Conclusion}

Far from being monolithic, the mechanisms of musical censorship in China take different forms: institutional, practical, and discretionary. In fact, the NRTA, and previously the SAPPRFT, is supposed to monitor and enforce government cultural policies at each administrative level. In practice, there are different ways to contend with these guidelines, whether in the release of music albums, the uploading of online tracks, or the organisation of concerts. The example of the punk rock community reveals how certain groups play with censorship by changing certain lyrics. The publication of albums by private stakeholders is also permitted by the introduction of state-owned companies on the market, which are required to find ways to self-finance, even if this means selling the rights to release albums to independent labels, while checking the ideological content of these albums. In the same way, the organisation of concerts falls within a grey area, involving negotiations with local authorities and distribution of bribes. This does not stop the authorities from intervening directly at concerts and festivals by muting the sound or by carrying out drug tests.

In recent years, and especially since Xi Jinping came into office, the cultural and musical field has been controlled more closely. On the institutional front, the SAPPRFT, formerly under government control, has been dissolved into the NRTA, directly supervised by the Communist Party. In practical terms, it has become more difficult to organise concerts because of new tax policies and police raids, while relations between the audience and police officers are getting more violent. The famous 2018 so-called "hip-hop ban" and its subsequent back-pedalling show the delays and amateurism of censorship, at the risk, however, of forgetting more worrisome discretionary decisions. The removal of many songs from online streaming platforms, targeting songs dating back in some instances to the 1980s, as well as the disappearance of Li Zhi, point to the possibility of a gradual distancing between independent music and the public domain. This echoes the much more disturbing current state of Uyghur music, whose most popular artists are criminalised by the Party-state, such as the pop singer Ablajan Awut Ayup, as well as the musician and dutar player Sanubar Tursun (Anderson and Byler 2019). Understanding and analysing the mechanisms of Chinese censorship and its latest evolutions helps to better grasp the current state of music in the Sinophone world, as Hong Kong and Taiwanese artists have to comply with the ideological demands of the Communist Party in order to continue to perform in the PRC - a new era that calls to mind Li Zhi's premonitory warning featured in one of his songs, "The people don't need freedom, this is the best era." ${ }^{143}$

\section{Translated by Romain Dittgen.}

\section{Dr. Nathanel Amar is a Researcher and the Director of the CEFC Taipei office (namar@cefc.com.hk).}

Manuscript received on 7 March 2019. Accepted on 23 July 2019.

42. Holmes Chan, "Hong Kong says pro-independence Taiwan band member barred as he lacks 'special skills, knowledge or experience'," Hong Kong Free Press, 24 December 2018, https://www. hongkongfp.com/2018/12/24/hong-kong-says-pro-independence-taiwan-band-member-barredlacks-special-skills-knowledge-experience/ (accessed on 30 June 2019).

43. “人民不需要自由, 這是最好的年代” (Renmin bu xuyao ziyou, zhe shi zuihao de niandai). See Li Zhi performing the song during a concert: https://www.youtube.com/watch?v=fKYfH3N9KzA (accessed on 30 June 2019).

\section{Primary Sources}

CD-Rev 天賦事變. 2016. “紅色力量” (Hongse liliang, The Force of Red). Youtube (PRC). https://youtu.be/5cWQGDW8Jb0 (accessed on 30 June 2019) [Music Video].

CUI, Jian 崔健. 1987. 新長征路上的搖㳘 (Xin changzheng lushang de yaogun, Rock'n'Roll on the New Long March). Zhongguo lüyou shengxiang (PRC) [Compact Disc].

DOU, Wei 賔唯. 1994. 黑夢 (Hei meng, Black Dreams). Magic Stone (PRC/Taiwan) [Compact Disc].

Dwagie 大支. 2019. "Tryna Bully." DashGo/Audiobee (Taiwan), Youtube. https://youtu.be/zAfiZ73FIsU (accessed on 2 November 2019) [Music Video].

GAI 周延. 2018. “萬裏長城” (Wanli changcheng, Great Wall). Beijing daxiang wuxing yinyue (PRC), Youtube. https://youtu.be/ciZvgDvcc38 (accessed on 30 June 2019) [Music Video].

HE, Yong 何勇. 1994. 垃圾場 (Laji chang, Garbage Dump). Magic Stone (PRC/Taiwan) [Compact Disc].

Hei Bao 黑豹. 1991. 黑豹 (Hei Bao, Black Panther). Magic Stone (PRC/ Taiwan) [Compact Disc].

In3 陰三兒. 2008. 未知㙯術家 (Weizhi yishujia, Unknown Artist). Self- produced (PRC) [Compact Disc].

CHEUNG Jacky 張學友. 1990. 人間道 (Jan gaan dou, The Way of Man). Universal Music (Hong Kong) [Compact Disc].

LI, Zhi 李志. 2005. 梵高先生 (Fangao xiansheng, Mr. Van Gogh). Koudai changpian (PRC) [Compact Disc].

LO, Ta-yu 羅大佑, and Ram CHIANG 蔣志光. 1991. 皇后大道東 (Wong hau daai dou dung, Queen's Road East). R\&B Studio (Hong Kong) [Compact Disc].

Tang Dynasty 唐朝. 1992. 夢回唐朝 (Menghui Tangchao, A Dream Return to Tang Dynasty). Magic Stone (PRC/Taiwan) [Compact Disc].

SMZB 生命之餅. 2001.50,000. Scream Records (PRC) [Compact Disc].

SMZB 生命之餅. 2014. 中國來信 (Zhongguo laixin, A Letter from China). Maybe Mars (PRC) [Compact Disc].

Sober 清醒. 1997. 好極了?! (Hao ji le?!, Is it alright?!). Modern Sky (PRC) [Compact Disc].

UnderBaby 地下嬰兒. 1998. 覺醒 (Juexing, Awakening). Rock Records (PRC/Taiwan) [Compact Disc].

Wuliao Jundui 無聊軍隊. 1999. 無聊軍隊 (Wuliao Jundui, The Boredom Contingent). Scream Records (PRC) [Compact Disc]. 


\section{References}

AMAR, Nathanel. 2018. "'Do you Freestyle?' The Roots of Censorship in Chinese Hip-Hop." China Perspectives 1-2(113): 107-13.

ANDERSON, Amy, and Darren BYLER. 2019. "'Eating Hanness': Uyghur Musical Tradition in a Time of Reeducation." China Perspectives 3(118): 17-26.

BARANOVITCH, Nimrod. 2003. China's New Voices: Popular Music, Ethnicity, Gender, and Politics, 1978-1997. Berkeley: University of California Press.

BERRY, Chris. 2004. Postsocialist Cinema in Post-Mao China: The Cultural Revolution after the Cultural Revolution. New York: Routledge.

CAMPBELL, Jonathan. 2011. Red Rock. The Long, Strange March of Chinese Rock \& Roll. Hong Kong: Earnshaw Books.

CAPDEVILLE-ZENG, Catherine. 2002. "Les spectacles de musique rock en Chine. Du yin et du yang" (Rock performances in China. Some yin and yang). L'Homme 161: 123-48.

DE KLOET, Jeroen. 2010. China with a Cut: Globalisation, Urban Youth and Popular Music. Amsterdam: Amsterdam University Press.

DE KLOET, Jeroen. 2005. "Popular Music and Youth in Urban China: The Dakou Generation." The China Quarterly 183: 609-26.

GAO, Dan. 2014. "From Pirate to Kino-Eye: A Genealogical Tale of Film Re-Distribution in China." In Matthew D. Johnson, Keith B. Wagner, Tianqi Yu, and Luke Vulpiani (eds.), China's iGeneration. Cinema and Moving Image Culture for the Twenty-first Century. London: Bloomsbury. 125-46.

GOLD, Thomas B. 1993. "Go with Your Feelings: Hong Kong and Taiwan Popular Culture in Greater China." The China Quarterly 136(December): 907-25.

GRAEZER, Florence. 1999. "The 'Yangge' in Contemporary China: Popular Daily Activity and Neighbourhood Community Life." China Perspectives 24(July-August): 31-43.

GRILLOT, Caroline. 2001. "Dixia Chengdu/Chengdu Underground." Ateliers 24. http://journals.openedition.org/ateliers/8721 (accessed on 30 June 2019).

GROENEWEGEN, Jeroen. 2011. Tongue. Making sense of Underground Rock, Beijing 1997- 2004. Sarrebruck: Lambert Academic Publishing.

HAN, Rongbin. 2015. "Defending the Authoritarian Regime Online: China's 'Voluntary Fifty-cent Army'." The China Quarterly 224(December): 1006-25.

HU, Mingrong. 2005. "State Press and Publication Administration." In Edward L. Davis (ed.), Encyclopedia of Contemporary Chinese Culture. New York: Routledge. 781.

HUANG, Hao. 2001. "Yaogun Yinyue: Rethinking Mainland Chinese Rock'n'Roll." Popular Music 20(1): 1-11.

JONES, Andrew F. 1992. Like a Knife: Ideology and Genre in Contemporary Chinese Popular Music. Ithaca: Cornell University Press.
JU, Qihong 居其宏. 2002. 新中國音樂史. 1949-2000 (Xin Zhongguo yinyue shi. 1949-2000, A History of Chinese Music. 1949-2000). Hunan: Hunan meishu chubanshe.

LATHAM, Kevin. 2005. "State Administration for Radio, Film and Television." In Edward L. Davis (ed.), Encyclopedia of Contemporary Chinese Culture. New York: Routledge. 778-9.

MAO, Zedong. 1942. Talks at the Yenan Forum on Literature and Art. Online: https://www.marxists.org/reference/archive/mao/selectedworks/volume-3/mswv3_08.htm (accessed on 30 June 2019).

NG, Jason. 2013. Blocked on Weibo: What Gets Suppressed on China's Version of Twitter (and why). New York: The New Press.

O'DELL, David. 2011. Inseparable. The Memoirs of An American And the Story of Chinese Punk Rock. Portland: Manao Books.

OU, Ning 歐寧, YAN Jun 顏峻, and NIE Zheng 聶筝. 1999. 北京新 聲 (Beijing Xinsheng, New Sound of Beijing). Changsha: Hunan yishu chubanshe.

PERNIN, Judith. 2015. Pratiques indépendantes du documentaire en Chine. Histoire, esthétique et discours visuels (1990-2010) (Independent Practices of Documentary in China (1990-2010)). Rennes: Presses Universitaires de Rennes.

STEEN, Andreas. 2000. "Sound, Protest and Business. Modern Sky Co. and the New Ideology of Chinese." Berliner China-Hefte 19: 40-64. http://www.china-rock.de/rock.pdf (accessed on 30 June 2019).

TANG, Lijun, and Peidong YANG. 2011. "Symbolic Power and the Internet: The power of a 'Horse'." Media, Culture \& Society 33(5): 67591.

THIREAU, Isabelle, and Linshan HUA. 2010. Les ruses de la démocratie. Protester en Chine (Ruses of democracy: Protesting in China). Paris: Le Seuil.

TREBINJAC, Sabine. 2000. Le pouvoir en chantant. Vol. 1 (Power through Singing). Paris: Société d'ethnologie.

VEG, Sebastian. 2007. "Eliminating Disharmony: Recent Examples of Censorship in Chinese Writing and Cinema." China Perspectives 3(71): 66-72.

WILCOX, Emily. 2020. "When Folk Dance Was Radical: Cold War Yangge, World Youth Festivals, and Overseas Chinese Leftist Culture in the 1950s and 1960s." China Perspectives 1(120): 33-42.

XUE, Ji 雪季. 1993. 搖滾夢尋. 中國搖滾樂實錄 (Yaogun mengxun. Zhongguo yaogun shilu, Looking for Chinese rock. The archives of Chinese rock). Beijing: Zhongguo Dianying chubanshe.

YANG, Peidong, and Lijun TANG. 2018. "Positive Energy. Hegemonic Intervention and Online Media Discourse in China's Xi Jinping Era." China: An International Journal 16(1): 1-22.

ZHANG, Ge, and Jian XU. 2019. "A Brief Genealogy of Hanmai." China Perspectives 3(118): 63-8. 